\title{
Serum ferritin concentration and iron stores in normal subjects
}

\author{
G. O. WALTERS, F. M. MILLER, AND M. WORWOOD \\ From the Department of Haematology, Welsh National School of Medicine, Heath Park, Cardiff
}

SYNOPSIS The relationship between serum ferritin concentration and the amount of storage iron has been studied in normal subjects. A high degree of correlation was demonstrated between serum? ferritin concentration and storage iron measured by quantitative phlebotomy. The possible advant- in ages of assessing iron stores by using the serum ferritin concentration are discussed.

Ferritin is the main iron storage compound in the body and is present mainly in the reticuloendothelial cells of the liver, spleen, and bone marrow. A small amount is normally found in the circulating plasma, the concentration varying between 10 and $200 \mu \mathrm{g}$ per litre (Jacobs, Miller, Worwood, Beamish, and Wardrop, 1972). The mean concentration in men is twice that in women suggesting that the serum level reflects total body stores. This is supported by the observation that patients with irondeficiency anaemia have concentrations below $10 \mu \mathrm{g}$ per litre and patients with iron overload have greatly increased levels (Jacobs et al, 1972). Although there is a good correlation between serum ferritin concentration and iron load in pathological states there is no evidence that this correlation exists in normal subjects.

The most accurate method for measuring iron stores is by quantitative phlebotomy (Haskins, Stevens, Finch, and Finch, 1952; Weinfeld, 1970). This gives a measure of the amount of iron available for haemoglobin synthesis, the so-called mobilizable iron stores. This paper reports on the relationship between iron stores in normal subjects measured by this method and serum ferritin concentration.

\section{Subjects and Methods}

SUB JECTS

Twenty-two apparently healthy normal adult subReceived for publication 11 July 1973. jects gave their fully informed consent to this study. 은 The group included 12 males aged 19 to 46 years and 10 females aged 22 to 40 years. Their haematological characteristics (means and range) were as shown in table I.

Five of the males were blood donors but none had given blood in the three months before the studg $\omega$ and their iron status was considered to be in equi librium. Their haematological characteristics dif not differ significantly from those of other me

\section{METHODS}

Serial phlebotomies of approximately $400 \mathrm{ml}$ were performed at weekly intervals in the majority of the subjects. Some were bled more frequently but intervals greater than eight days were exceptional.

Phlebotomy was continued until the following criteria were satisfied: (1) The haemoglobin concentration fell below $11 \mathrm{~g}$ per $100 \mathrm{ml}$ and was maintained at this level without further phlebotomy for a period of 14 days. (2) The transferrin saturation was consistently below $15 \%$, indicating depletion of iron stores (Bainton and Finch, 1964).

After each phlebotomy the volume of blood removed was measured and its haemoglobin $\frac{}{0}$ concentration determined. Serum iron, total ironbinding capacity, and ferritin concentrations were $\mathcal{N}$ also determined.

Haematological parameters were measured using $N$ the Coulter $\mathbf{S}$ automatic cell counter. Serum iron concentration and total iron-binding capacity were

\begin{tabular}{llll}
\hline & Haemoglobin $(\mathrm{g} / 100 \mathrm{ml})$ & Mean Corpuscular Volume $(\mathrm{f})$ & Transferrin Saturation $(\%)$ \\
\hline Men (12) & $14 \cdot 2(13 \cdot 0-15 \cdot 0)$ & $89(82-94)$ & $20(14-39)$ \\
Women (10) & $13 \cdot 0(12 \cdot 1-14 \cdot 1)$ & $88(78-94)$ & $(9-41)$ \\
\hline
\end{tabular}

Table I Haematological characteristics 
measured by a modification of the method of Young and Hicks (1965). Serum ferritin concentration was measured by using the immunoradiometric assay of Addison, Beamish, Hales, Hodgkins, Jacobs, and Llewellin (1972). The amount of storage iron was calculated by the method of Haskins, Stevens, Finch, and Finch (1952). The total amount of iron removed by phlebotomy was calculated from the quantity of haemoglobin removed. Iron lost in reducing the subjects' haemoglobin concentration from its initial to its final value was calculated using an estimated blood volume (Nadler, Hidalgo, and Bloch, 1962). The difference between these values represents the total amount of mobilizable storage iron. A correction for the amount of iron absorbed during the study, estimated as $3 \mathrm{mg}$ daily, was also made (Haskins et al, 1952; Olsson, 1972).

\section{Results}

Initial serum ferritin concentrations ranged from 2 to $83 \mu \mathrm{g} /$ litre in the females (mean $35.6 \mu \mathrm{g} /$ litre) and from 36 to $224 \mu \mathrm{g} /$ litre in the males (mean 103 $\mu \mathrm{g} / \mathrm{litre}$ ). There was a significant difference between the male blood donors and non-donors, with mean values of 64 and $132 \mu \mathrm{g} /$ litre respectively.

Storage iron in female subjects was $0-340 \mathrm{mg}$ (mean $210 \mathrm{mg}$ ) and in males $140-1390 \mathrm{mg}$ (mean $690 \mathrm{mg}$ ). The male blood donors again gave significantly lower results with mean stores of $400 \mathrm{mg}$ compared with $900 \mathrm{mg}$ in the non-donors.

There was a close correlation between the serum ferritin concentration and mobilizable iron stores (fig $1, \mathrm{r}=0.83, \mathrm{P}<0.001$ ). The relation between these two parameters is expressed by the equation $y=11.8+0.13 x$, where $y$ is the ferritin concentration in $\mu \mathrm{g} /$ litre and $x$ is the storage iron in milligrams. The correlation when iron stores are uncorrected for absorbed iron was similar $(r=0.80$, $\mathrm{P}<0.001)$. The correlation between the calculated total circulating ferritin and iron stores was also very similar $(r=0.843, \mathrm{P}<0.001)$.

Ferritin concentration fell as phlebotomy was repeated. In all cases the fall in ferritin concentration preceded or coincided with a fall in transferrin

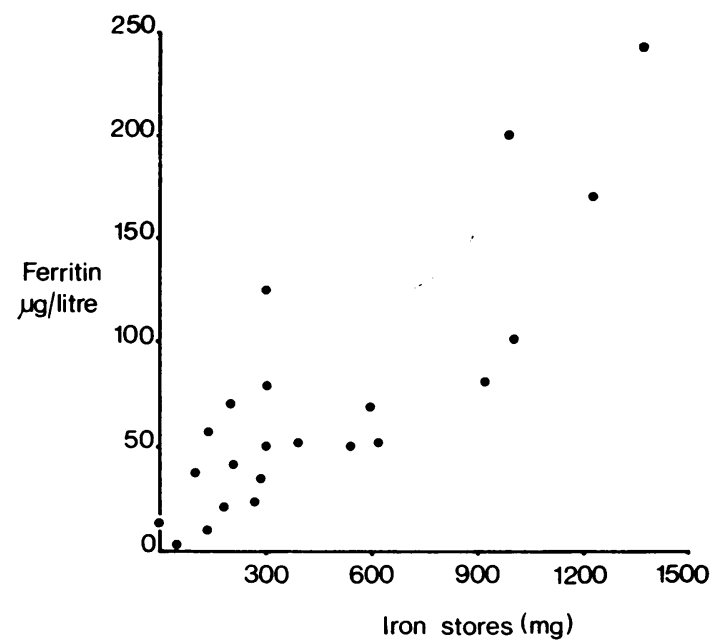

Fig 1 Iron stores and serum ferritin concentration.

saturation, the former was the more usual pattern whilst the latter tended to occur in those subjects with the least iron stores.

\section{Discussion}

The results obtained for iron stores in both males and females are in close agreement with published values using quantitative phlebotomy and they show the same wide variation. Published values (means in $\mathrm{mg}$ ) with the authors and numbers of subjects in brackets are as shown in table II.

Quantitative phlebotomy is the standard reference method for assessing iron stores and measures the amount of mobilizable iron available for haemoglobin synthesis. In practice it is a lengthy and inconvenient procedure for which indirect, though more convenient methods, are usually substituted. Some, like the visual assessment of iron in marrow or liver biopsies, cannot be quantitated. The quantitative methods include the estimation of desferrioxamine-induced urinary excretion (Olsson, 1972; Balcerzak, Westerman, Heinle, and Taylor, 1968) and non-haem iron concentration in liver (Weinfeld, 1970). Both these techniques give results which

\begin{tabular}{|c|c|c|c|}
\hline Author & Males & Females & Blood Donors \\
\hline $\begin{array}{l}\text { Olsson (1972) } \\
\text { Balcerzak et al (1968) }\end{array}$ & $\begin{array}{l}750(11) \\
687(11) \\
819\end{array}$ & & $110(14)$ \\
\hline $\begin{array}{l}\text { Pritchard and Mason (1964) } \\
\text { Haskins et al (1952) }\end{array}$ & $\begin{array}{ll}819 & (3) \\
844 & (2)\end{array}$ & 254 (10) & $93 \quad(2)$ \\
\hline $\begin{array}{l}\text { Hynes (1949) } \\
\text { Present data } \\
\text { Mean of all series }\end{array}$ & $\begin{array}{l}600 \quad(1) \\
900 \text { (7) } \\
767(35)\end{array}$ & $\begin{array}{l}210(10) \\
232(20)\end{array}$ & $400 \quad(5)$ \\
\hline
\end{tabular}

Table II Published values for iron stores 
correlate with mobilizable stores but both involve the patient in some inconvenience. In addition it is clear that some of the iron available for chelation by desferrioxamine is not derived from storage compounds (Olsson, 1972; Balcerzak et al, 1968; Karabus and Fielding, 1967). The desferrioxamine test involves one or two intramuscular injections followed by a 6 to 24-hour urine collection and a biopsy is necessary to determine the non-haem iron content of liver. These procedures have to be compared to the single sample of venous blood required for measurement of ferritin concentration.

Direct measurement of a segment of the body ferritin pool appears to give a valid indication of total body iron stores both in normal subjects and in those with iron deficiency and iron overload. The present data suggest that $1 \mu \mathrm{g}$ ferritin per litre of serum represents about $8 \mathrm{mg}$ of storage iron. In a series of 75 healthy males and 44 healthy females the mean serum ferritin concentration was 69 and 35 $\mu \mathrm{g}$ per litre respectively (Jacobs et al, 1972) corresponding to mean iron stores of $552 \mathrm{mg}$ in the men and $280 \mathrm{mg}$ in the women.

We should like to thank Abbott Laboratories and the Leukaemia Research Fund for their support.
References

Addison, G. M., Beamish, M. R., Hales, C. N., Hodgkins, M., Jacobs, A., and Llewellin, P. (1972). An immunoradiometric assay for ferritin in the serum of normal subjects and patients with iron deficiency and iron overload. J. clin. Path., 25, 326-329.

Bainton, D. F., and Finch, C. A. (1964). The diagnosis of iron deficiency anaemia. Amer. J. Med., 37, 62-70.

Balcerzak, S. P., Westerman, M. P., Heinle, E. W., and Taylor, F. H. (1968). Measurement of iron stores using desferrioxamine. Ann. intern. Med., 68, 518-525.

Haskins, D., Stevens, A. R., Jr., Finch, S., and Finch, C. A., (1952). Iron metabolism. Iron stores in man as measured by phlebotomy. J. clin. Invest., 31, 543-547.

Hynes, M. (1949). The iron reserves of a normal man. J. clin. Path., 2, 99-102.

Jacobs, A., Miller, F., Worwood, M., Beamish, M. R., and Wardrop, C. A. (1972). Ferritin in the serum of normal subjects and patients with iron deficiency and iron overload. Brit. med.J., 4, 206-208.

Karabus, C. D., and Fielding, J. (1967). Desferrioxamine chelatable iron in haemolytic, megaloblastic and sideroblastic anaemias, Brit. J. Haemat., 13, 924-933.

Nadler, S. B., Hidalgo, J. U., and Bloch, T. (1962). Prediction of blood volume in normal human adults. Surgery, 51, 224-232.

Olsson, K. S. (1972). Iron stores in normal men and male blood donors. Acta med. scand., 192, 401-407.

Pritchard, J., and Mason, R. A. (1964). Iron stores of normal adults and replenishment with oral iron therapy. J. Amer. med. Ass., 190, 897-901.

Weinfeld, A. (1970). Iron stores. In Iron Deficiency: Pathogenesis, Clinical Aspects and Therapy, edited by L. Hallberg, $H$. Harwerth, and A. Vannotti, p. 329-372. Academ ic Press, London and New York.

Young, D. S., and Hicks, J. M. (1965). Method for the automatic $\vec{\theta}$ determination of serum iron. J. clin. Path., 18, 98-102. 